\title{
ASSESSING THE RELATIONSHIP BETWEEN INDUSTRY CHARACTERISTICS AND ORGANIZATIONAL CULTURE: HOW DIFFERENT CAN YOU BE?
}

\author{
JENNIFER A. CHATMAN \\ University of California, Berkeley \\ KAREN A. JEHN \\ University of Pennsylvania
}

\begin{abstract}
This study investigated the relationship between two industry characteristics, technology and growth, and organizational culture. We examined this relationship by comparing the cultures of organizations within and across industries. Using 15 firms representing four industries in the service sector, we found that stable organizational culture dimensions existed and varied more across industries than within them. Specific cultural values were associated with levels of industry technology and growth. One implication of this finding is that the use of organizational culture as a competitive advantage may be more constrained than researchers and practitioners have suggested.
\end{abstract}

Organizations have discernible differences based on industry norms (cf. Pennings \& Gresov, 1986). Just as task environments affect how organizations are structured, assumptions about important constituents lead to similar values among same-industry organizations (Gordon, 1991). In an effort to understand the forms and consequences of organizational culture, researchers have explored how various processes, such as individual and organizational selection and socialization (Harrison \& Carroll, 1991), and characteristics of powerful members - such as an organization's founder (e.g., Boeker, 1989; Schein, 1985) or groups of members (e.g., Schneider, 1987)influence the content and intensity of and the consensus that exists about organizational values. In addition to these internal features, features present in the industry an organization operates in, such as the technology used and the rate of growth, may also affect the uniqueness of an organization's culture. Of course, such influence does not preclude meaningful cultural variation across firms in the same industry, but less variation may occur among firms working on the same tasks, using similar procedures, and experiencing similar opportunities to grow than occurs across industries. Since little theo-

We thank Paul Hirsch, Dawn Iacobucci, Charles O'Reilly, Edward Zajac, Raymond Zammuto, and an anonymous reviewer for their constructive comments on this article and Elizabeth Morrison, Blair Sheppard, and John Sheridan for help with the data collection. 
retical attention and even less empirical research has focused on the effects of industry membership on organizational culture (Dansereau \& Alluto, 1990), in the present study we sought to understand this important source of influence.

We began by distinguishing between industry culture and the effects of industry characteristics on organizational culture. Focusing on the influence of industry characteristics on organizational culture explicitly acknowledges that culture also varies across organizations, even among firms in very homogeneous industries (e.g., Chatman, 1991). Further, from a functionalist perspective, organizational culture may only be a source of sustained competitive advantage if it is valuable, rare, and imperfectly imitable (Barney, 1986). Therefore, it is important to understand the extent to which cultural variation actually exists across firms and industries and to distinguish actual variation from a mere illusion of uniqueness (Martin, Feldman, Hatch, \& Sitkin, 1983).

Our understanding of the relationship between industry characteristics and organizational culture is constrained by empirical weaknesses in previous research. For example, samples have been small and unrepresentative (Grinyer \& Spender, 1979) and industry categorization schemes too general to yield insights about the relationship between industry characteristics and organizational culture (Gordon, 1985). Qualitative approaches (Phillips, 1991) have generated rich descriptions of industry cultures, but they make comparisons across organizations difficult. Further, previous studies have examined multiple business sectors, such as service and production, making it difficult to determine whether findings should be attributed to industry effects or, rather, to the sector in which industry members operated (e.g., Hofstede, Neuijen, Ohayv, \& Sanders, 1990).

To understand how industry characteristics affect organizational culture, and particularly the cultural variation across firms and industries, research should (1) clarify the level of analysis that allows for systematic comparisons within and across industries, (2) identify particular industry characteristics that influence organizational culture, and (3) control for business sector. In this study, we compared organizational cultures to assess the extent of variation within and across industries. We focused on the influence of two important industry characteristics, technology and growth, on organizational culture. We included only service sector firms and examined multiple firms within four distinct industries. This study therefore increases conceptual understanding of the variation and content of organizational culture by investigating the influence of industry characteristics.

\section{ORGANIZATIONAL CULTURE IN THE SERVICE SECTOR}

Popular writers and academics agree that shared understandings of a firm's culture enhance strategy implementation, organizational change, and positive images of the firm in clients' eyes (Deal \& Kennedy, 1982; Kotter \& Heskett, 1992; Wilkins \& Ouchi, 1983). Having a set of values that is both 
widely shared and strongly held by members - a "strong" culture (O'Reilly, 1989) - may be especially beneficial to firms operating in the service sector since members of these organizations are responsible for delivering the service and for evaluations important constituents make about firms (George \& Marshall, 1984). For example, a public accounting firm's clients develop perceptions about the firm through contact with the particular accountants who work on their engagements (Stevens, 1981). Because on-site accountants' work styles and attitudes may be the only true contact clients have with the firm, accountants must behave in ways that are consistent with their firm's culture. And this is easier for members to do if they understand their organizational culture (e.g., Morrison, 1993).

Further, direct supervision is more difficult in the service sector than in the manufacturing sector because of the high frequency of off-site work, multiple engagements, and the high proportion of professional staff members (Magnet, 1993; Normann, 1984). In contrast, manufacturing is conducive to formal control mechanisms because processes and products are more tractable (e.g., Bravermann, 1974). Consequently, service sector firms rely heavily on social control mechanisms, such as cultural values, to direct members' actions (O'Reilly, 1989). Because these shared values are internalized, they can apply to a broad range of appropriate behavioral responses that are hard for managers to anticipate and formalize in unsupervised situations (Ouchi \& Johnson, 1978). We focused on service sector firms because of the need to control for sector but also did so because the service sector, which plays the largest role in employment and national U.S. income, is underrepresented in organizational research (e.g., Lewis, Siemen, Balay, \& Sakate, 1992).

\section{Viewing Organizational Culture as Values}

In this study, we conceptualized and quantified organizational culture in terms of widely shared and strongly held values, and we examined the effects of industry characteristics on organizational culture by assessing the similarities and differences in firm cultures within and across industries. The elements of organizational culture range from fundamental assumptions through values and behavioral norms to actual patterns of behavior (Rousseau, 1990). Values typically act as the defining elements of a culture, and norms, symbols, rituals, and other cultural activities revolve around them (Enz, 1988). When the members of a social unit share values, an organizational culture or value system can be said to exist (Weiner, 1988).

Of course, focusing on organization-level values does not deny the existence or importance of firm subcultures (e.g., Jerimer, Slocum, Fry, \& Gaines, 1991; Sackmann, 1992). To a certain extent, organizations vary in terms of the level at which their values are the most widely shared; for instance high unit-specific consensus may characterize some firms, and high organization-level consensus may typify others. Following other authors (e.g., Van Maanen \& Barley, 1984), we suggest that almost every organization has some core values that are shared across the entire organization. Indeed, 
Selznick (1957) argued that shared values are essential for organizational survival because they maintain the organization as a bounded unit and provide it with a distinct identity.

Characterizing an organization's culture in terms of its central values requires identifying the range of relevant values and then assessing how strongly held and widely shared they are (e.g., Saffold, 1988). In a sample of United States firms, O'Reilly, Chatman, and Caldwell (1991) identified the following seven dimensions of organizational culture using an instrument they developed, the Organizational Culture Profile (OCP): innovative, stable, respecting of people, outcome oriented, detail oriented, team oriented, and aggressive. Interestingly, these culture dimensions are quite similar to Hofstede and colleagues' (1990) practice dimensions generated from an international sample of firms. The OCP dimensions also resemble two of the four types of cultural knowledge that Sackmann (1992) found generalized across a single organization. "Directory knowledge," or what people do in an organization, resembles "working long hours" and "paying attention to detail," and "recipe knowledge" resembles norms such as "respect for individuals" rights" and "fitting in."

Authors have generated many culture dimensions over the past few decades (e.g., Denison, 1990; Rousseau, 1990; Zammuto \& Krakower, 1991). Although there are some general similarities among various authors' categories, it is important to establish a robust set of culture dimensions that can characterize organizational cultures. Demonstrating that a set of replicable dimensions exists is a prerequisite to making meaningful comparisons across organizations and industries. Of course, replicability does not imply that all organizations will be characterized by the same magnitude of a culture dimension. For example, organizations will certainly vary in their levels of innovation, but innovation remains a relevant dimension on which organizational cultures can be described. Our proposition functions as a prerequisite to more specific hypotheses about the relationship between culture and industry characteristics:

Proposition 1: Organizational cultures, within and across industries, can be characterized by seven dimensions: innovation, stability, respect for people, outcome orientation, detail orientation, team orientation, and aggressiveness.

\section{Links Between Industry Characteristics and Organizational Culture}

Research has shown that technology is related to organizational forms and performance (e.g., Aldrich, 1972; Perrow, 1967; Van de Ven \& Delbecq, 1974) and that growth rate is a determinant of business strategy (cf. Dess \& Beard, 1984). Under a similar logic, technology and growth can also be related to organizational culture (e.g., Quinn \& Rohrbaugh, 1983; Zammuto \& O'Connor, 1992) and account for cultural similarities among sameindustry firms. 
Technology. One of the most salient similarities among firms in the same industry is their technology. If organizational culture represents how things are done within particular organizations (e.g., Deal \& Kennedy, 1982), technology constrains the variation in how things are done by defining what is being done. Thus, greater similarities in the content and processes of task completion across firms in the same industry will be associated with less variation in their organizational cultures.

One way to conceptualize this relationship is to associate Thompson's (1967) technological classification scheme with specific dimensions of organizational culture. Thompson's typology is appropriate in this study because it includes a critical element for service sector firms, clients, or customers. Industries can be classified into three groups. Long-linked, or serially interdependent, technologies are exemplified by assembly line tasks. Such tasks have prescribed orders and predictable cause-effect relationships and are highly structured. In the service sector, firms operating in the transportation industry use long-linked technologies. Mediating technologies standardize processing by sorting inputs and clients into groups and apply prescribed procedures based on those categorizations. Examples are product engineering firms, banks, and insurance claim units (Rousseau, 1977). Intensive, or custom, technologies use techniques that vary according to the specific demands of a project. Intensive technologies typically have low cause-effect relationships and require extensive problem-solving activities. Examples are R\&D units, hospitals, and consulting firms.

Thompson's (1967) classification of technological forms can be viewed as a continuum ranging from long-linked through mediating to intensive (Hitt \& Middlemist, 1978; Jelinek, 1977). Rousseau (1977) argued that Thompson's typology is based on the amount of discretion required for production: long-lined organizations have little demand for discretion, mediating organizations require some discretion in standardizing procedures, and intensive technologies require a great deal of discretion. Similarly, Hitt and Middlemist (1978) showed that technological complexity increases from long-linked through mediating to intensive technologies.

Growth. Empirical research has shown that size and technology "track" together (e.g., Dewar \& Hage, 1978), and diversification growth in industries is linked to technological development (Gort, 1962). Indeed, technological progress driven by a desire to reduce uncertainty (Thompson, 1967) frequently fosters growth (Katz \& Kahn, 1966). New technologies and improved methods are typically incorporated because they are related to an industry's type of work (Pfeffer \& Salancik, 1978), and adoption of these advances often increases production capacity (Zammuto \& O'Connor, 1992). Therefore, industry growth may, similarly, relate to organizational culture (Gordon, 1985).

In a high-growth industry, many firms will experience resource munificence, generated by the constantly increasing revenues and opportunities (Cyert \& March, 1963; Dess \& Beard, 1984). Industry growth also influences the extent to which organizations attempt to strategically manage interde- 
pendencies and complexities, behaviors that are reflected in organizational culture (Harrison \& Carroll, 1991; Zammuto \& O'Conner, 1992). Such growth can affect organizational culture by, for instance, increasing risk taking and innovation (Gordon, 1991). These arguments about technology and growth suggest the following hypothesis regarding variation in culture across firms and industries:

Hypothesis 1: The magnitudes of dimensions of organizational culture will vary more across industries than across firms operating in the same industry.

More specific predictions can be made about the magnitude of the cultural dimensions firms in particular industries are likely to share. In particular, firms in industries characterized by intensive technologies should have cultures characterized by high levels of innovation, since projects require nonroutine problem solving (Pennings \& Harianto, 1992), and by a strong team orientation, since such ill-structured tasks are more likely to require that members collaborate to solve problems (e.g., Kanter, 1988). Opportunities for growth may, similarly, influence innovation (Gordon, 1985; Rosner, 1968) and a firm's desire to be unique or rare (Barney, 1986). For example, high growth rates increased innovation and flexibility among hightechnology firms in Silicon Valley (Saxenian, 1990). In contrast, the cultures of firms in industries characterized by long-linked technologies should be characterized by high levels of stability, since tasks are repetitive and predictable, and by a strong detail orientation, since only refinements to processes are required (Hofstede et al., 1990). Likewise, low-growth industries, such as utilities, depend upon stability and reliability (Gordon, 1985).

Firms in industries with mediating technologies and moderate levels of growth will have modest levels of the culture dimensions rather than the high or low levels found in the long-linked or intensive technologies. Specifically, since firms using mediating technologies do not require as much structuring of jobs as those using long-linked technologies, but are more standardized than intensive technologies (Hitt, 1976), they will be less likely to emphasize innovation in their cultures than firms using intensive technologies (Saxenian, 1990), but they will also be less likely to emphasize stability in their cultures than the highly structured firms using long-linked technologies. Hitt and Middlemist (1978) suggested that the level of detail orientation among the cultures of firms that are members of industries employing mediating technologies would be moderate rather than extreme. More formally, we predict that industry characteristics will be related to the content of an organization's culture in the following ways:

Hypothesis 2a: Firms in industries characterized by intensive technologies and high growth will have cultures that more strongly emphasize innovation and team orientation than firms in industries characterized by mediating technologies and moderate growth and firms in in- 
dustries characterized by long-linked technologies and low growth, respectively.

Hypothesis 2b: Firms in industries characterized by longlinked technologies and low growth will have cultures that more strongly emphasize stability and detail orientation than firms in industries characterized by mediating technologies and moderate growth and firms in industries characterized by intensive technologies and high growth, respectively.

Hofstede and colleagues (1990) suggested that all service sector organizations will be more people oriented than outcome oriented. But generalizing across service sector organizations on any of the seven dimensions, given differing technology and growth rates, may cause one to overlook important cultural differences. Addressing nonroutine problems often requires input from a variety of experts, and implementing an innovation requires that individuals with varying backgrounds work together effectively (e.g., Kanter, 1988). Similarly, rapid growth implies an intense, hard-driving work pace and a lack of predictability, circumstances under which it is difficult to completely specify jobs in advance. Thus, job incumbents in growing firms must be relied upon to invent new ways of adapting to change and uncertainty. Organizations use organizational culture, or social control, to instill pride in membership, intensity, and feelings of loyalty among organization members. This process ensures that members' objectives correspond to organizational objectives (O'Reilly, 1989). In addition, high growth significantly influences employee stability, a potential source of innovation (e.g., Freeman, 1982), and may increase a firm's emphasis on human resource issues (e.g., Harrison \& Carroll, 1991; Pfeffer, 1982). For example, Saxenian (1990) found that firms within the high-growth semiconductor industry had cultures that emphasized people orientation, innovation, and customer service. In contrast, firms in low-growth industries rely on formal control mechanisms, such as policies and procedures, to direct members' efforts (e.g., Wilkins \& Ouchi, 1983). Therefore, consistent with Hypothesis 2 , we expected the magnitude of the measured levels on culture dimensions to be the reverse of the intensive technology, high-growth firm pattern for the long-linked technology, low-growth firms. More formally,

Hypothesis 3a: Firms in industries characterized by intensive technologies and high growth will have cultures characterized more by people orientation, team orientation, and innovation than by outcome orientation, stability, easygoingness, and detail orientation.

Hypothesis 3b: Firms in industries characterized by longlinked technologies and low growth will have cultures characterized more by outcome orientation, stability, 
easygoingness, and detail orientation than by people orientation, team orientation, and innovation.

Hypothesis 3c: Firms in industries using mediating technology and experiencing moderate growth will have cultures characterized by equivalent levels of people, team, outcome and detail orientation, innovation, stability, and easygoingness.

In sum, we tested predictions about the content of an organization's culture based on a knowledge of the technology and growth of the industry in which the organization operated.

\section{METHODS}

\section{Firms}

Fifteen U.S. firms representing four industries in the service sector participated in this study. We classified the firms into industries using fourdigit Standard Industrial Classification (SIC) codes (Candilis, 1988). The firms included eight of the largest U.S. public accounting firms (industry 8721), three general consulting firms (industry 8742), one government and transportation firm (the U.S. Postal Service, industry 4311), and three national household goods carrier firms (industry 4213).

\section{Measures}

Organizational culture. To assess organizational culture, we used the Organizational Culture Profile (OCP, O'Reilly et al., 1991), which is based on the Q-sort profile comparison process (Bem \& Funder, 1978; Block, 1978). In a Q-sort, respondents are presented with a large number of items and asked to sort them into a specific number of categories based on some criterion. The OCP contains 54 "value statements" assessing attitudes toward, for instance, quality, respect for individuals, flexibility, and risk taking that emerged from a review of academic and practitioner-oriented writings on organizational values and culture. Thirty-eight business administration majors and four business school faculty members screened an initial 110-item deck for items that were redundant, irrelevant, difficult to understand, or omitted. A similar check was made with an independent set of respondents from accounting firms. After several iterations, a final set of 54 values was retained (O'Reilly et al., 1991).

A number of tests have been conducted to assess the reliability and validity of the OCP. Test-retest reliability over a 12-month period was quite high (median $r=.74$, range $=.65-.87$ ). To avoid social desirability bias, O'Reilly and colleagues cast the OCP items in neutral terms, and comparisons to an empirically derived profile of social desirability revealed that firm informants did not sort the items in ways that made their firms look good (Chatman, 1991). In addition, convergent validity has been established through the significant positive correlation $(r=.28, p<.05)$ between per- 
son-organization fit assessed with the OCP and normative commitment defined as attachment to an organization based on value congruence (O'Reilly et al., 1991).

Three distinct advantages of this semiidiographic approach to assessing organizational culture are (1) since each item is implicitly compared to every other item, the outcome of a Q-sort is a realistic profile with items arranged in an order that reflects the relative importance of each item to each other item; (2) culture strength is captured by assessing the similarity of members' perceptions of organization values (tested with reliability coefficients and interrater correlations) and the intensity with which values are held (examining the most extreme items such as the top and bottom items); and (3) meaningful comparisons across profiles (individuals, firms, or individuals and firms) are possible (Chatman, 1989). ${ }^{1}$

To assess organizational culture, members who were familiar with their organizations' cultures were asked to sort the 54 values into nine categories ranging from "most characteristic of my firm's culture" to "most uncharacteristic of my firm's culture." Fewer cards were allowed at the extreme ends and more were allowed in the middle, more neutral categories; the specific number of cards to be placed in each of the nine categories was $2,4,6,9,12$, 9,6 , 4, and 2. Respondents from the public accounting firms included 284 partners and managers; the mean number of respondents per firm was 35.5. For each participating firm, respondents were drawn from offices in the same three major U.S. regions (except for two firms in which one region did not participate). Seventy-six percent of the respondents were men, and their tenure with their firms averaged 8.04 years. In the three consulting firms, 65 partners representing a total of eight major regional offices across the United States participated (a mean per firm of 21.67). Of the partners, 65 percent were men, and tenure with their firms averaged 7.51 years. The three freight transport firms' respondents consisted of 88 managers (the mean per firm was 29.33) working at their headquarter offices. Forty-eight percent were women, and firm tenure averaged 13.9 years. The U.S. Postal Service group consisted of 720 middle-level managers representing 74 regions. They were attending a continuing management development program at an East Coast university, and 88 percent were men with an average tenure of 21.4 years. Table 1 provides a more detailed description of firm-level sample characteristics.

An implicit assumption in the use of the OCP is that a single profile can

\footnotetext{
${ }^{1}$ One potential drawback of using a Q-sort method to assess organizational culture is that items are not strictly independent of one another. Specifically, raters are constrained in the number of discriminations they are allowed to make. But computing the number of different ways in which the 54 culture items can be arranged into the designated nine categories reveals that there are many different ways to sort the items $\left(3.1 \times 10^{42}\right)$. Thus, any two items are relatively independent (the intercorrelation of each item with each other item is approximately - .02). Researchers who use the Q-sort method argue that item analysis, in a conventional rating scale, is therefore acceptable (Block, 1978).
} 
TABLE 1

Respondents' Characteristics by Firm

\begin{tabular}{lccccl}
\hline Firm & $\boldsymbol{N}$ & $\begin{array}{c}\text { Number of } \\
\text { Regions }\end{array}$ & $\begin{array}{c}\text { Average } \\
\text { Age }\end{array}$ & $\begin{array}{c}\text { Average } \\
\text { Tenure }\end{array}$ & Job Level \\
\hline Accounting 1 & 48 & 3 & 48.52 & 9.61 & Managers/partners \\
Accounting 2 & 37 & 3 & 47.12 & 8.98 & Managers/partners \\
Accounting 3 & 43 & 3 & 45.37 & 8.48 & Managers/partners \\
Accounting 4 & 28 & 3 & 44.28 & 7.26 & Managers/partners \\
Accounting 5 & 32 & 3 & 45.56 & 6.97 & Managers/partners \\
Accounting 6 & 17 & 2 & 44.47 & 7.68 & Managers/partners \\
Accounting 7 & 43 & 3 & 45.38 & 7.23 & Managers/partners \\
Accounting 8 & 36 & 2 & 46.57 & 8.11 & Managers/partners \\
Consulting 1 & 21 & 3 & 37.44 & 8.24 & Partners \\
Consulting 2 & 29 & 2 & 38.92 & 6.92 & Partners \\
Consulting 3 & 15 & 3 & 38.54 & 7.36 & Partners \\
Household goods & & & & & \\
$\quad$ carrier 1 & 29 & Headquarters & 37.20 & 13.60 & Managers \\
Household goods & & & & & \\
$\quad$ carrier 2 & 28 & Headquarters & 40.10 & 12.30 & Managers \\
Household goods & & & & & \\
$\quad$ carrier 3 & 31 & Headquarters & 39.80 & 15.80 & Managers \\
Post office & 720 & 74 & 45.90 & 21.40 & Managers \\
\hline
\end{tabular}

represent the value system of a firm. Speaking of a profile of an organization's culture is only meaningful when there is high consensus among members about organizational values. We averaged the OCPs that respondents Q-sorted item-by-item to obtain an overall profile for each firm. Using the Spearman-Brown prophecy formula (Nunnally, 1967: 211) we found that the coefficient alphas emerging from these profiles ranged from .84 to .94. These reliability coefficients are interpreted slightly differently when a Q-sort is used (e.g., Nunnally, 1967: 226). In this case, each coefficient represents how similar each member's rating of a firm is to that firm's total profile. In other words, it is an estimate of how likely we would be to get the same firm (mean) profile if we had asked everyone in each firm, rather than a sample of informants, to sort the OCP. These high scores clearly indicate that a representative profile of organizational culture was captured for each of the firms (Jones \& James, 1979).

Shared perceptions, or agreement among firm members about firm culture, can also be represented by how closely any two raters view the firm culture, on average, and high median correlations indicate small within-firm variance (Jones, Johnson, Butler, \& Main, 1983). To assess such agreement, we calculated the average pairwise correlation coefficient across all pairs of individual raters within each firm. Across the 15 firms, the correlations between any two raters within the same firm ranged from -.020 to .839 . More important, median within-firm correlations among raters ranged from .257 , for a freight company, to .664 , for a consulting firm, and the median within-firm correlation for the entire data set was $.441(\bar{x}=.436$, s.d. $=$ 
.121). This level of agreement is consistent with those of previous research (e.g., Joyce \& Slocum, 1984; Sheridan, 1992) and is especially impressive given the multiple regions represented in the accounting and consulting firm groups. Taken together, the alpha coefficient and the average pairwise correlations reflect a high level of agreement in perceptions of organizationlevel culture.

Industry characteristics: Technology. The post office and the household goods carriers included in this study can be characterized as delivery firms using long-linked technologies. The post office describes its business operations as "collecting, processing and delivering the nation's mail . . . transforming an ocean of raw mail into orderly flowing channels of letters, cards, parcels, advertising, magazines and newspapers" (United States Postal Service, 1992a: 7). The U.S. Postal Service operates within the context of a highly traditional governmental bureaucracy and must adhere to an extensive set of formalized rules and regulations (Gramlach, 1985). Similarly, the business operations of the household goods carriers industry is described as "the management of the movement of goods through space (by transport) and through time (by warehousing, storage, production scheduling, and related activities) from their first origins as raw materials to their final destinations in consumers' hands" (Sampson, Farris, \& Shrock, 1985: 16).

The accounting industry provides accounting services, which can be described as "recording all of an entity's transactions and similar relevant events, grouping those transactions and events in categories with similar characteristics, and presenting them in a set of financial statements intended to meet the needs of a variety of users" (Stevens, 1981: 5). These activities are based on industrywide standards and prescribed procedures, the generally accepted accounting principles (GAAP) developed by the Financial Accounting Standards Board, an independent regulatory agency. Thus, the public accounting industry technology focuses on sorting inputs and clients into groups and applying prescribed procedures based on those categorizations.

Although the services that consulting firms offer vary, including information systems, strategic planning, and human resources, all such firms follow a similar pattern of activities that involves substantial discretion on the consultants' part. These include generating proposals, defining problems, gathering data, analyzing data, diagnosing problems, and making recommendations (Kelley, 1986; Kubr, 1976). Problem solving and creative thinking are an integral part of consulting - both of which suggest illstructured problems and low cause-effect relationships.

We classified these four industries according to Thompson's typology, drawing on the organization's descriptions of their work, annual reports supplied by firms in each industry, the four-digit SIC classifications, and judgments made by four business school professors familiar with Thompson's typology, each of whom independently categorized the industries into exactly the same categories. The U.S. Postal Service and the freight transport firms were classified as having long-linked technologies, the eight public 
accounting firms were classified as having mediating technologies, and the consulting firms were classified as having intensive technologies.

Among firms operating in the service sector, the product, or value contributed to clients, resides in employees' and professionals' knowledge, skills, and abilities. Technological intensity, or the extent to which members have technical training based on systematic knowledge of a profession and adhere to professional norms (Gort, 1962; Wilensky, 1964), is also an indicator of technology. Among the industries represented in this study, only 11 percent of U.S. Postal Service employees have greater than a high school degree (United States Postal Service, 1992b). Similarly, only 23 percent of employees in the household goods carriers industry have some college education, and only 2 percent have completed graduate education (Household Goods Carriers Bureau, 1992). In contrast, in the public accounting industry 83 percent of the employees have a college education and 45 percent have advanced degrees or certifications (Darnay, 1992). Similarly, in the consulting industry only 19.4 percent of employees have just a college education, and 67 percent have graduate training (Association of Management Consultant Firms, 1987). The order in which these industries are arrayed on the technological intensity continuum matches our other industry measures and previous technological classifications across industries (e.g., Rousseau, 1977).

Industry characteristics: Growth. The growth rate in each of the four industries was defined as (1) the percent change in revenues and (2) the percent change in number of employees (Pfeffer, 1982). We compiled these statistics for each industry for the five years prior to our collection of data on culture (Darnay, 1992; United States Department of Commerce, 1985, 1989, 1992; United States Postal Service, 1986, 1988, 1992a, 1992b). The average increase in revenues over five years for the post office was 4.40 percent (s.d. $=3.33 \%$ ); for the household goods carriers industry, it was 5.87 percent (s.d. $=1.33 \%$ ); for the accounting industry, it was 7.21 percent (s.d. $=5.40 \%$ ); and for the consulting industry, it was 14.10 percent (s.d. $=4.03 \%$ ). The average increase in employees over five years for the post office was 1.20 percent (s.d. $=.21 \%$ ); for the household goods carriers, it was 1.10 percent (s.d. $=1.20 \%$ ); for the accounting industry, it was 4.25 percent (s.d. $=$ $3.37 \%$ ); and for the consulting industry, it was 8.32 percent (s.d. $=4.12 \%$ ). Once again, the ordering of these indicators was consistent with our technology classification.

Representativeness. It was important to ensure that the firms selected in this study were representative of firms in their respective industries to rule out selection bias (Dess, Ireland, \& Hitt, 1990). Concentration figures show how resources in the industries are distributed among firms. Typically, concentration is measured as the proportion of the market accounted for by the eight largest firms in an industry (Pfeffer \& Salancik, 1978). Each of the firms in this study was one of the top eight firms in its industry for market share based on total revenue for the SIC group: household goods carriers was 90.9 percent; the three firms studied had market shares of $14.86,7.50$, and 27.36 
percent. The largest eight accounting firms hold 91.0 percent of the market in public accounting (because of two major mergers, this market share was held by six firms after 1989); the firms we studied held 20, 11, 9, 10, 9, 9, 13, and 10 percent. The largest eight consulting firms jointly held 86.3 percent of the industry's market; the three participating firms held 11.7, 9.5, and 8.9 percent (Darnay \& Reddy, 1992). The concept of concentration is not applicable to monopolies such as the post office, but in one market in which the post office does compete, express mail, the top three carriers, of which the postal service is one, make up 90 percent of the market.

Size and revenue indicators also showed that the firms studied were equivalently major players within their industries. For example, each firm had more than 4,000 employees at the time the study was conducted (U.S. Postal Service $=793,937$; household goods carriers, 5,868, 3,325, and 7,000 members; public accounting firms, 14,337, 7,990, 6,892, 9,530, 6,397, 6,132, 10,732, and 9,435 professionals; and consulting firms, 4,659, 4,731, and 4,348 professionals). Each firm's revenues exceeded 200 million dollars at the time of data collection (U.S. Postal Service, $\$ 35$ billion; household goods carriers, \$399, \$213, and \$776 million; public accounting firms, \$1,182, $\$ 645, \$ 528, \$ 545, \$ 755, \$ 513, \$ 1,004$, and $\$ 809$ million; and consulting firms, $\$ 861, \$ 666$, and $\$ 667$ million).

\section{RESULTS}

\section{The Dimensionality of Organizational Culture}

The OCP responses for each firm were factor-analyzed with a principal component analysis and a varimax rotation. Results of an analysis of the entire item set showed that 38 of the 54 items loaded above .30 on one of seven distinct factors. Table 2 shows these results. We did not use items with significant cross-loadings (above .30 on two or more factors) in further analyses but present them in Table 2 to allow for comparisons to O'Reilly and colleagues' (1991) factor structure results.

From a scree test, seven interpretable factors with eigenvalues greater than 1.0 and defined by at least two items emerged: (1) innovation, (2) stability, (3) an orientation toward people, (4) an orientation toward outcomes or results, (5) an emphasis on being easygoing, (6) attention to detail, and (7) a collaborative or team orientation. The correlations among the factors are quite low, ranging from .002 (people oriented and easygoing) to .328 (innovative and outcome oriented) with a median correlation of .046. Six of the factors are identical to O'Reilly and colleagues' (1991) factor results. The single differing factor was labeled "aggressive" by those authors and "easygoing" by us. These two factors can be viewed as opposites on the same dimension.

We also calculated canonical correlations (Cliff, 1987; Green, 1978). Although the basic question answered by canonical correlation analysis is whether there is any association between two sets of data, in the present context this technique allowed us to compare the factor pattern of each firm 


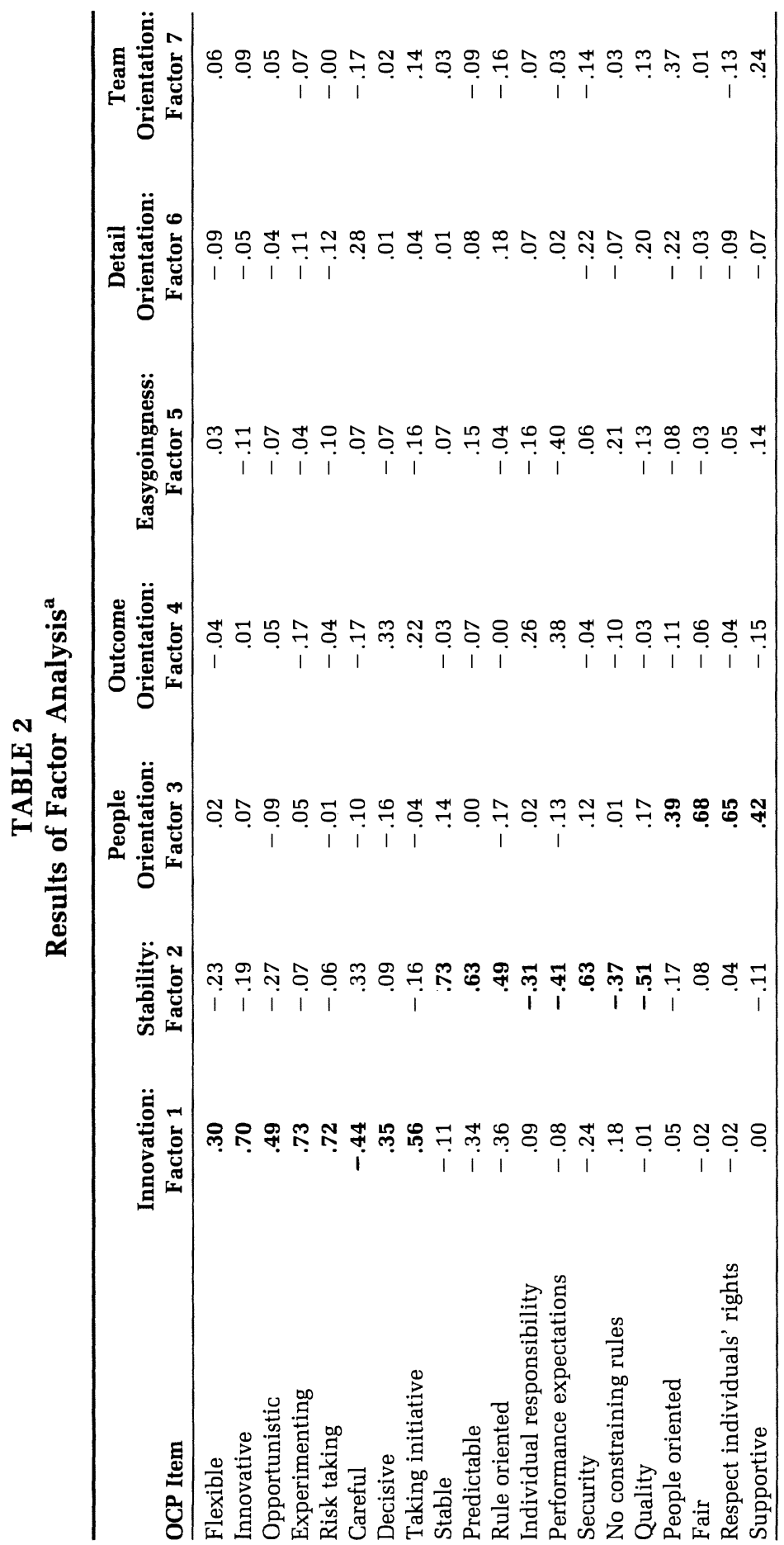




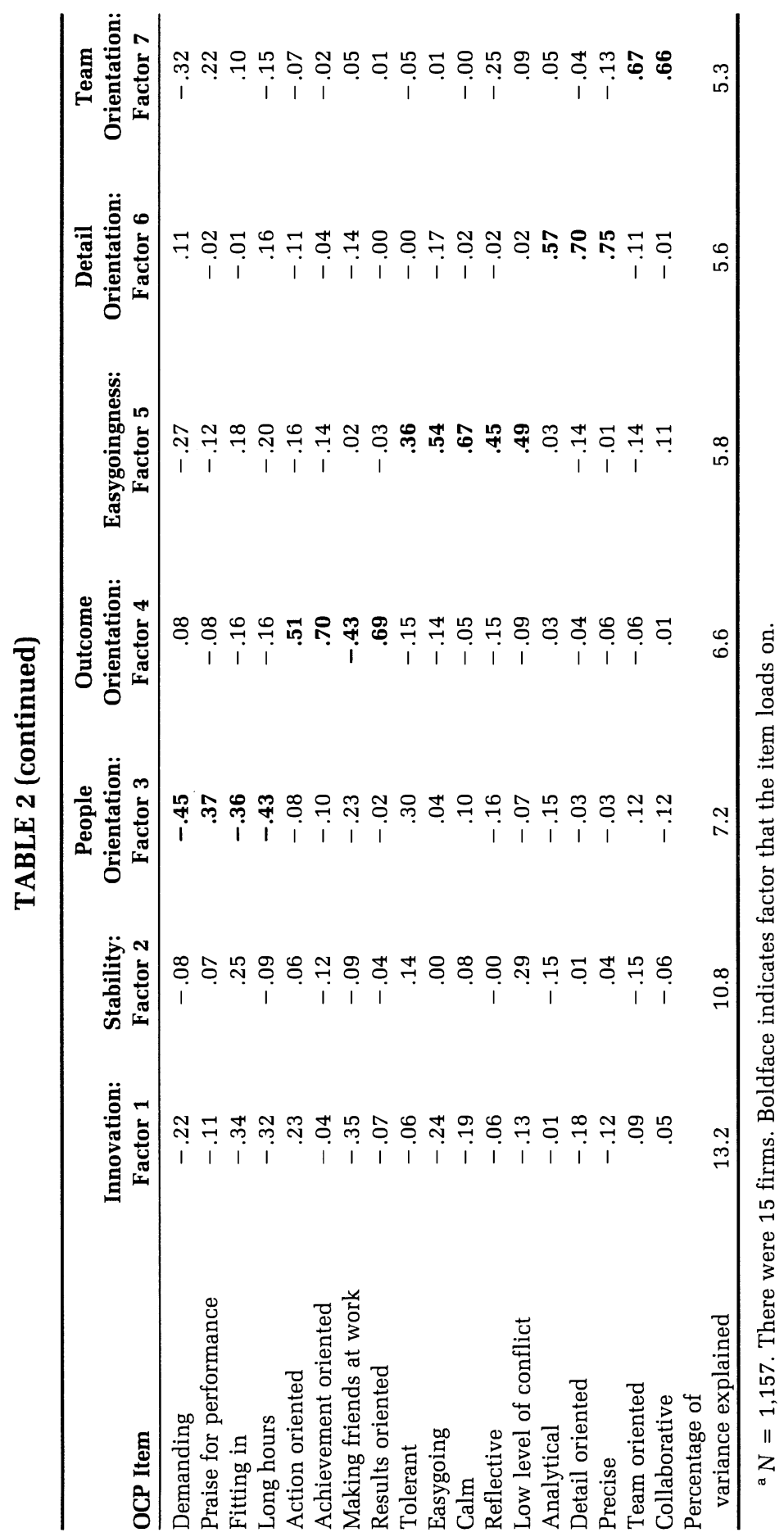


to a "target" consisting of all firms minus the firm being compared (to eliminate common method bias). The results of these analyses (one for each of the 15 firms) indicated that the factors are indeed common across firms, or that the factor structure is consistent. When compared to the population target, each firm had a significant $(p<.0001)$ squared canonical correlation, as follows: accounting 1 (the first accounting firm) $=.84$, accounting $2=.74$, accounting $3=.82$, accounting $4=.87$, accounting $5=.86$, accounting $6=$ .86 , accounting $7=.85$, accounting $8=.81$; consulting $1=.75$, consulting $2=.75$, consulting $3=.68$; U.S. Postal Service $=.89$; household goods carrier $1=.74$, carrier $2=.76$, carrier $3=.66$. Thus, as Proposition 1 states, it appears that the OCP dimensions generalize to a large set of heterogeneous organizations and are applicable across organizations and industries.

\section{Comparing Firm and Industry Differences in Organizational Culture}

To assess whether the culture dimensions varied more across than within industries (Hypothesis 1), we conducted analyses of variance (ANOVAs) using, for each firm, item factor scores averaged across raters. The Fs for these analyses are a measure of the variance explained by the firm, when so grouped, or by the industry. Fs for the ANOVA that used firm as the criterion were significant for each of the seven dimensions $(p<.0001)$ : innovation $=8.16$; stability $=39.28$; people orientation $=3.62$; outcome orientation $=2.10$; easygoingness $=10.39$; detail orientation $=6.61$; team orientation $=3.80$. Thus, even within the service sector firms have unique cultures. Fs for the ANOVA that used industry as the criterion were also significant $(p<.0001)$ and substantially larger for six of the seven factors: innovation $=20.69$, stability $=160.36$, people orientation $=11.27$; outcome orientation $=.83$ (n.s.); easygoingness $=26.20$; detail orientation $=$ 14.51 ; team orientation $=7.61$. In sum, although the organization level is important in explaining the variance in cultures, industry differences explain more variance than organization differences for six of the seven culture dimensions, supporting Hypothesis 1.

A more detailed analysis of these differences can be generated from planned pairwise comparisons for each pair of firms on each factor. This analysis also assesses which culture dimensions vary most. For example, there were 34 significant comparisons on the stability factor. Of these, 31 resulted from comparing across industries and only 3 resulted from withinindustry comparisons. Similarly, of the 19 significant paired comparison differences on the innovation factor, 13 resulted from across-industry comparisons, and only 6 emerged from within the same industries. As for the five remaining factors, people orientation had 16 significant comparisons, 12 from across and 4 from within industries; outcome orientation had 16 significant comparisons, 10 from across and 6 from within industries; easygoingness had 40 significant comparisons, 27 from across and 13 from within industries; detail orientation had 28 differences, 25 from across and 3 from within industries; and team orientation had 7 significant comparisons, 7 from across and 0 from within industries. Thus, all the culture dimensions 
again varied more across industries than within them (Hypothesis 1). In fact, with the postal service held out since it is the only firm in its industry, there are 9 significant differences across the three industries out of a possible 21 (three industries multiplied by seven dimensions), or in other words, 43 percent of the dimensions vary across industries; but across firms within each of the three industries, 34 significant differences out of 238 exist. Thus, the average percentage of significant differences within industries is substantially smaller $(14 \%)$ than the across-industry percentage. Easygoingness, innovation, and outcome orientation vary most within industries (across firms), and detail orientation, easygoingness, and stability vary most across industries.

\section{Technology, Growth, and Culture}

After demonstrating that culture generally varies more across than within industries, we examined whether certain technologies and growth patterns were associated with certain culture dimensions, as specified in Hypotheses 2a, 2b, 3a, 3b, and 3c. In Hypothesis 2a we suggested that firms in industries characterized by intensive technologies and high growth would be more likely to have cultures characterized by innovation and a strong team orientation than firms using mediating technologies and experiencing moderate growth and firms using long-linked technologies and experiencing slow growth. We performed planned comparison tests across industries after averaging firm scores (see Table 3 and Figure 1). Contrary to Hypothesis 2a, the consulting firms were not significantly higher (or lower) on innovation than any of the other industries. The consulting firms also ranked significantly lower than the accounting firms on team orientation. Hypothesis 2a was supported in that the accounting firms (mediating technology and moderate growth) were significantly higher than the postal service (long-linked technology and low growth) on innovation and higher than both the postal service and the household goods carriers (long-linked technology and low growth) on team orientation.

We also suggested that firms using long-linked technologies and experiencing low growth would be more likely to have cultures characterized by stability and detail orientation than firms using mediating technology and experiencing moderate growth and firms using intensive technologies and experiencing rapid growth (Hypothesis $2 \mathrm{~b}$ ). Consistent with this prediction, the postal service was significantly higher on stability than the other three industries; however, the household goods carriers were only significantly higher than the accounting firms on stability. Contrary to Hypothesis $2 b$, the postal service and the freight carriers were both significantly lower than the accounting and consulting firms on detail orientation.

Hypotheses 3a, 3b, and 3c compare culture dimensions within firms across industries. Specifically, Hypothesis 3a predicts that higher levels of people orientation, team orientation, and innovation than of outcome orientation, stability, easygoingness, and detail orientation will characterize the consulting firms' cultures, and that the magnitudes of these dimen- 


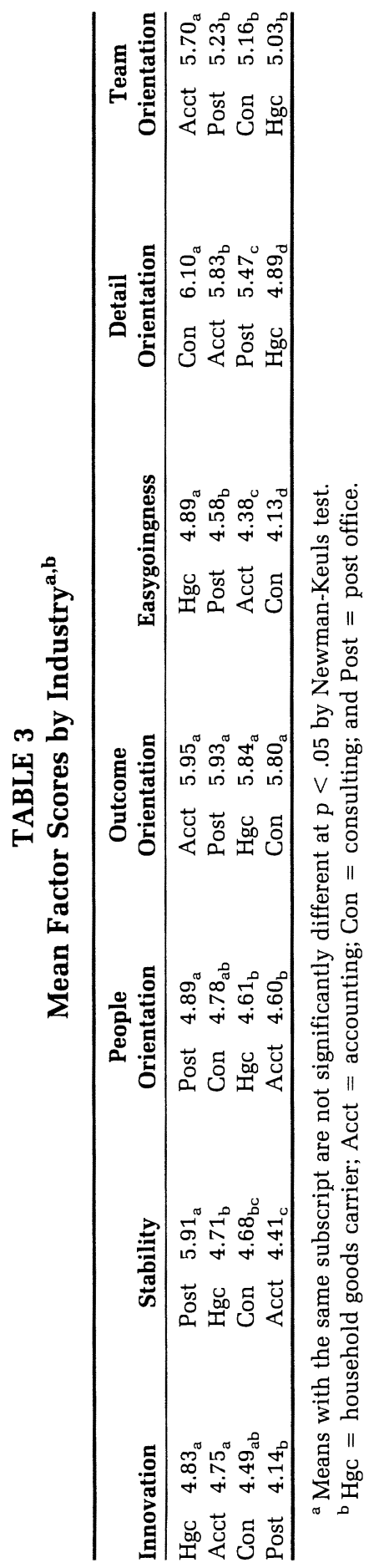


FIGURE 1

Comparisons of Industry Differences in Organizational Culture

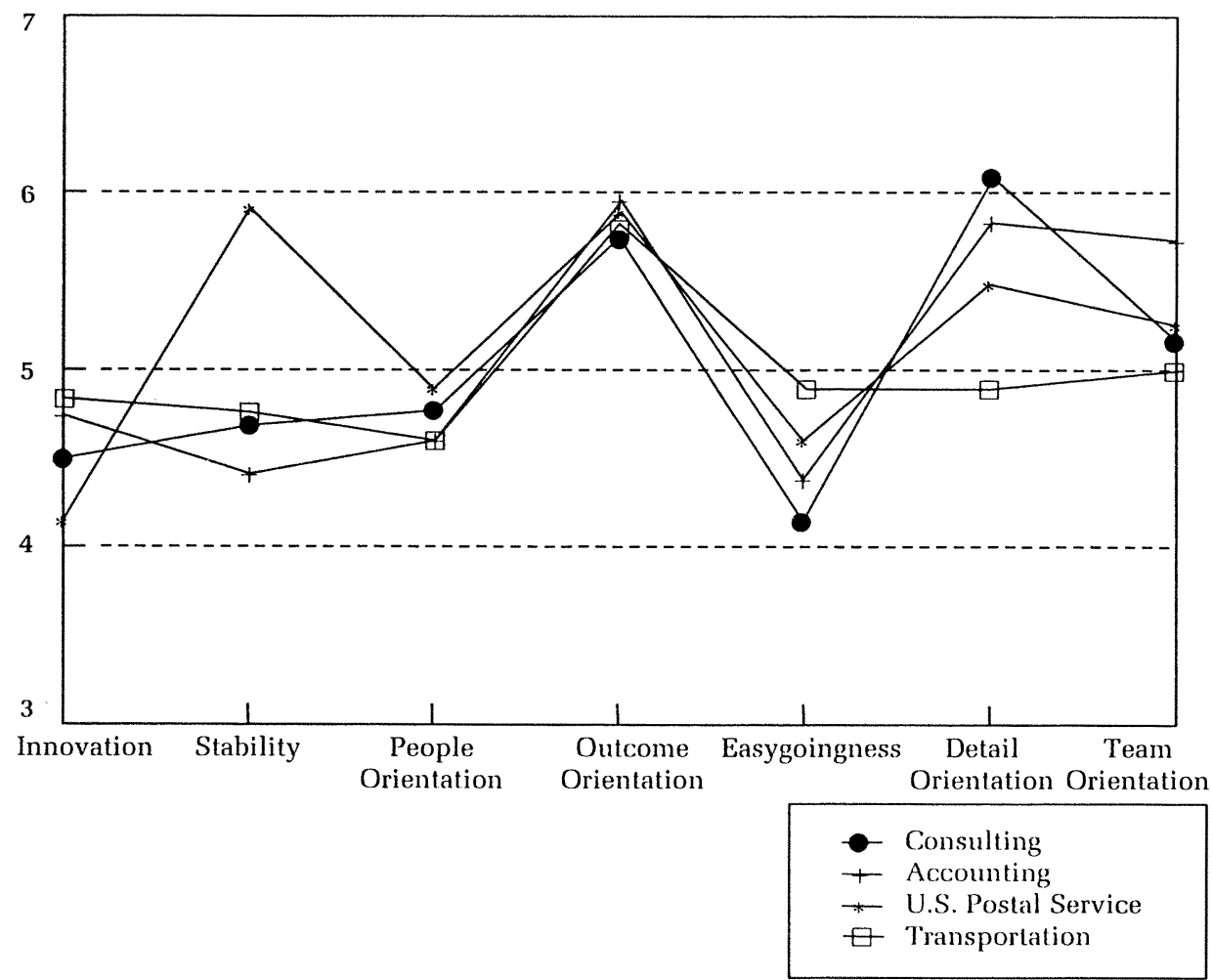

sions will be reversed for the household goods carriers and the postal service. We conducted an ANOVA across dimensions within each set of firms to test this set of predictions. Hypothesis 3a was only partially supported for the consulting firms. Although the dimensions varied significantly $(F=$ $11.42, p<.0001$ ), they only partially followed our predictions when arrayed in magnitude from the highest to the lowest; in the following results, differing subscripts represent significant differences among dimensions, determined using t-tests $(p<.01)$ : detail orientation, $6.10_{a}$; outcome orientation, $5.80_{\mathrm{a}}$; team orientation, $5.16_{\mathrm{b}}$; people orientation, $4.78_{\mathrm{bc}}$; stability, $4.68_{\mathrm{bcd}}$; innovation, $4.49_{\mathrm{cd}}$; and easygoingness, $4.13_{\mathrm{d}}$. In support of Hypothesis $3 \mathrm{a}$, consulting firms' cultures were significantly more team oriented and people oriented than easygoing but, contrary to Hypothesis 3a, detail and outcome orientation characterized consulting firms' cultures more than any of the other dimensions.

The postal service culture closely resembled the pattern predicted in Hypothesis $3 b$. The dimensions varied significantly $(F=99.96, p<.01)$ and were arrayed as follows: outcome orientation, $5.93_{a}$; stability, $5.91_{a}$; detail orientation, $5.47_{b}$; team orientation, $5.23_{\mathrm{c}}$; people orientation, $4.89_{\mathrm{d}}$, easygo- 
ingness, $4.58_{\mathrm{e}}$; and innovation, $4.14_{\mathrm{f}}$. Except for easygoingness, which we predicted would be present at a higher level than team and people orientations, the postal service's culture dimensions are arrayed as expected. In contrast, in the other industry using a long-linked technology and experiencing low growth, the household goods carriers, there was minimal variation across the seven culture dimensions $(F=1.85 ; p<.10)$. However, some consistencies with Hypothesis $3 \mathrm{~b}$ emerged in the ordering of the dimensions: outcome orientation, $5.84_{\mathrm{a}}$; team orientation, $5.03_{\mathrm{ab}}$; detail orientation and easygoingness, $4.89_{\mathrm{b}}$; innovation, $4.83_{\mathrm{b}}$; stability, $4.71_{\mathrm{b}}$; and people orientation, $4.61_{\mathrm{b}}$. Outcome orientation was significantly higher than people orientation and innovation, as predicted, but detail orientation, easygoingness, and stability were not significantly higher (or lower) than these dimensions.

Finally, Hypothesis 3c predicts that the accounting firms' cultures (mediating technology, moderate growth) would have equivalent levels of the seven culture dimensions. In contrast to our prediction, the dimensions varied significantly $(F=28.90, p<.001)$ and were arrayed as follows: outcome orientation, $5.95_{a}$; detail orientation, $5.83_{a}$; team orientation, $5.70_{a}$; innovation, $4.75_{\mathrm{b}}$; people orientation, $4.60_{\mathrm{bc}}$; stability, $4.41_{\mathrm{bc}}$; and easygoingness, $4.38_{\mathrm{c}}$.

In addition to the differences in variance among dimensions across firms and industries, there were differences for some dimensions in variance across firms within industries. Although we did not generate specific hypotheses regarding the likely within-industry variation across the seven dimensions, this variation affects the interpretability of the hypothesized results. In particular, the more within-industry variation on a culture dimension, the less valid it is to group the firms together for comparison with other industries on this dimension. Table 4 presents the specific firm means on each of the seven culture dimensions, and Table 5 summarizes the number of significant differences within industries across culture dimensions (the postal service was removed because it is a single firm). In general, the consulting firms have the highest proportion of significant within-industry differences (.24). These cultural differences are greatest on easygoingness and outcome orientation, and, to a lesser extent, stability. The accounting firms are the most similar, within industry, of the three industries (.13). The greatest cultural variation among the accounting firms appears on easygoingness; there were fewer on innovation, outcome orientation, and detail orientation, trivial differences on people orientation and stability, and none on team orientation. Finally, the household goods carriers show moderate intraindustry variation (.19) and vary most on innovation and people orientation but show no differences on stability, outcome orientation, easygoingness, detail orientation, and team orientation. Thus, within each industry the firms are similar on team orientation (of course, as reported in Table 3, the accounting firms are significantly higher than the other industries' firms), but there are differences of varying degrees among the firms on the other six dimensions. Given the fragmentation among same-industry firms, it may be 
TABLE 4

Mean Factor Scores by Firm ${ }^{\text {a,b }}$

\begin{tabular}{|c|c|c|c|}
\hline Firms & Means & Firms & Means \\
\hline Innovation & & Stability & \\
\hline Acct 6 & $5.62_{\mathrm{a}}$ & Post & $5.89_{a}$ \\
\hline Hgc 3 & $5.43_{\mathrm{ab}}$ & Hgc 1 & $5.40_{\mathrm{ab}}$ \\
\hline Hgc 2 & $5.26_{\mathrm{abc}}$ & Con 2 & $5.16_{\mathrm{bc}}$ \\
\hline Acct 7 & $5.11_{\mathrm{abcd}}$ & Acct 3 & $4.90_{\mathrm{bcd}}$ \\
\hline Con 1 & $4.91_{\mathrm{abcd}}$ & Con 3 & $4.80_{\text {bcde }}$ \\
\hline Acct 1 & $4.79_{\text {abcde }}$ & Hgc 3 & $4.70_{\text {bcde }}$ \\
\hline Acct 4 & $4.73_{\text {abcde }}$ & Acct 1 & $4.59_{\text {cdef }}$ \\
\hline Acct 3 & $4.66_{\mathrm{bcde}}$ & Acct 4 & $4.52_{\text {cdef }}$ \\
\hline Acct 8 & $4.52_{\text {bcde }}$ & Acct 8 & $4.50_{\text {cdef }}$ \\
\hline Acct 2 & $4.36_{\text {cde }}$ & Acct 5 & $4.36_{\text {cdef }}$ \\
\hline Con 3 & $4.32_{\text {cde }}$ & Acct 2 & $4.31_{\mathrm{def}}$ \\
\hline Con 2 & $4.24_{\mathrm{de}}$ & Acct 7 & $4.30_{\mathrm{def}}$ \\
\hline Acct 5 & $4.24_{\mathrm{de}}$ & Con 1 & $4.08_{\mathrm{def}}$ \\
\hline Post & $4.19_{\mathrm{de}}$ & Hgc 2 & $4.02_{\mathrm{ef}}$ \\
\hline Hgc 1 & $3.80_{\mathrm{e}}$ & Acct 6 & $3.78_{\mathrm{f}}$ \\
\hline Outcome orientation & & Easygoingness & \\
\hline Acct 1 & $6.24_{\mathrm{a}}$ & Acct 6 & $5.32 \mathrm{a}$ \\
\hline Con 1 & $6.21_{\mathrm{a}}$ & Hgc 2 & $5.22_{\mathrm{ab}}$ \\
\hline Acct 7 & $6.20_{\mathrm{a}}$ & Acct 5 & $4.90_{\mathrm{abc}}$ \\
\hline Acct 2 & $6.19_{\mathrm{ab}}$ & Hgc 3 & $4.75_{a b c}$ \\
\hline Hgc 2 & $6.05_{\mathrm{abc}}$ & Hgc 1 & $4.69_{\text {abcd }}$ \\
\hline Acct 8 & $6.00_{\mathrm{abc}}$ & Acct 3 & $4.66_{\mathrm{abcd}}$ \\
\hline Post & $5.93_{\mathrm{abcd}}$ & Post & $4.57_{\mathrm{bcd}}$ \\
\hline Acct 4 & $5.89_{\mathrm{abcd}}$ & Acct 4 & $4.50_{\mathrm{bcd}}$ \\
\hline Acct 6 & $5.85_{\mathrm{abcd}}$ & Con 1 & $4.45_{\mathrm{cd}}$ \\
\hline Hgc 3 & $5.79_{\mathrm{abcd}}$ & Con 2 & $4.36_{\mathrm{cde}}$ \\
\hline Con 3 & $5.73_{\mathrm{abcd}}$ & Acct 8 & $4.22_{\text {cdef }}$ \\
\hline Hgc 1 & $5.68_{b c d}$ & Acct 7 & $3.99_{\mathrm{def}}$ \\
\hline Acct 3 & $5.67_{b c d}$ & Acct 2 & $3.75_{\mathrm{ef}}$ \\
\hline Acct 5 & $5.53_{\mathrm{cd}}$ & Acct 1 & $3.67_{\mathrm{f}}$ \\
\hline Con 2 & $5.47_{d}$ & Con 3 & $3.59_{\mathrm{f}}$ \\
\hline Team orientation & & People orientation & \\
\hline Acct 7 & $6.10_{a}$ & Hgc 2 & $4.99_{\mathrm{a}}$ \\
\hline Acct 5 & $5.82_{\mathrm{ab}}$ & Con 3 & $4.93_{\mathrm{ab}}$ \\
\hline Acct 4 & $5.81_{\mathrm{ab}}$ & Post & $4.89_{a b c}$ \\
\hline Acct 6 & $5.80_{\mathrm{ab}}$ & Acct 6 & $4.84_{a b c}$ \\
\hline Acct 8 & $5.79_{\mathrm{ab}}$ & Acct 5 & $4.76_{\mathrm{abc}}$ \\
\hline Acct 3 & $5.53_{\mathrm{ab}}$ & Con 1 & $4.75_{\mathrm{abcd}}$ \\
\hline Acct 1 & $5.40_{\mathrm{abc}}$ & Acct 8 & $4.70_{\text {abcd }}$ \\
\hline Con 3 & $5.36_{\mathrm{abc}}$ & Con 2 & $4.68_{\mathrm{abcd}}$ \\
\hline Hgc 2 & $5.35_{a b c}$ & Acct 4 & $4.65_{\mathrm{abcd}}$ \\
\hline Acct 2 & $5.32_{a b c}$ & Acct 7 & $4.55_{\mathrm{bcd}}$ \\
\hline Con 2 & $5.32_{a b c}$ & Acct 1 & $4.51_{\mathrm{bcd}}$ \\
\hline Hgc 3 & $5.29_{\mathrm{abc}}$ & Hgc 3 & $4.49_{\mathrm{cd}}$ \\
\hline Post & $5.28_{\mathrm{abc}}$ & Acct 3 & $4.46_{\mathrm{cd}}$ \\
\hline Con 1 & $4.80_{\mathrm{bc}}$ & Hgc 1 & $4.35_{\mathrm{d}}$ \\
\hline Hgc 1 & $4.45_{c}$ & Acct 2 & $4.34_{\mathrm{d}}$ \\
\hline
\end{tabular}


TABLE 4 (continued)

\begin{tabular}{ll}
\hline Firms & Means \\
\hline Detail orientation & $6.24_{\mathrm{a}}$ \\
Acct 4 & $6.23_{\mathrm{a}}$ \\
Acct 3 & $6.20_{\mathrm{a}}$ \\
Con 2 & $6.16_{\mathrm{a}}$ \\
Con 3 & $6.10_{\mathrm{a}}$ \\
Acct 2 & $5.95_{\mathrm{ab}}$ \\
Con 1 & $5.91_{\mathrm{ab}}$ \\
Acct 5 & $5.71_{\mathrm{abc}}$ \\
Acct 7 & $5.59_{\mathrm{abc}}$ \\
Acct 1 & $5.52_{\mathrm{abc}}$ \\
Acct 8 & $5.45_{\mathrm{abc}}$ \\
Post & $5.18_{\mathrm{bcd}}$ \\
Hgc 3 & $5.16_{\mathrm{bcd}}$ \\
Acct 6 & $4.97_{\mathrm{cd}}$ \\
Hgc 1 & $4.53_{\mathrm{d}}$ \\
Hgc 2 & \\
\hline
\end{tabular}

${ }^{a}$ Means with the same subscript are not significantly different at $p<.05$ by Newman-Keuls test.

${ }^{\mathrm{b}} \mathrm{Hgc}=$ household goods carrier; Acct $=$ accounting; Con $=$ consulting; and Post $=$ post office.

more appropriate to examine firm means (rather than industry means) for certain industries and dimensions: this is the case for easygoingness and, to a lesser extent, for outcome orientation in the consulting and accounting industries and for innovation in the household goods carriers and accounting industries.

\section{DISCUSSION}

Our results offer some empirical support for similarities among the cultures of firms in the same industry and for a link between culture and industry characteristics, here conceptualized in terms of technology and growth rates. This study makes a number of important contributions. First, in a more heterogeneous and larger group of firms than has previously been studied, we were able to replicate the underlying factor structure of earlier studies of organizational culture (Hofstede et al., 1990; O'Reilly et al., 1991). Taken together with the canonical correlations, which show that the factor patterns among the firms studied here are similar, it appears that innovation, stability, an orientation toward people, an orientation toward outcomes or results, an emphasis on being easygoing, attention to detail, and a collaborative or team orientation are pervasive organizational culture themes.

Further, we found evidence for variance in the degree to which cultures emphasized each of the seven dimensions both across firms and across industries. As we predicted in Hypothesis 1, we found that, although both firm and industry membership accounted for significant variance, industry membership accounted for more differences in organizational culture on all the 


\section{TABLE 5}

Variation Within Industries Across Culture Dimensions

\begin{tabular}{|c|c|c|c|c|c|c|c|c|c|}
\hline Firms & $\boldsymbol{N}$ & $\begin{array}{c}\text { Propor- } \\
\text { tion }^{a}\end{array}$ & Number ${ }^{b}$ & $\begin{array}{l}\text { Propor- } \\
\text { tion }\end{array}$ & Number & $\begin{array}{l}\text { Propor- } \\
\text { tion }\end{array}$ & Number & $\begin{array}{l}\text { Propor- } \\
\text { tion }\end{array}$ & Number \\
\hline Consulting & 3 & 0 & 0 & .33 & 1 & 0 & 0 & .66 & 2 \\
\hline $\begin{array}{l}\text { Accounting } \\
\text { Household } \\
\text { goods }\end{array}$ & 8 & .14 & 4 & .04 & 1 & .07 & 2 & .14 & 4 \\
\hline carrier & 3 & .66 & 2 & 0 & 0 & .66 & 2 & 0 & 0 \\
\hline Total & 15 & .18 & 6 & .06 & 2 & .12 & 4 & .18 & 6 \\
\hline
\end{tabular}

${ }^{\text {a }}$ Entries represent the number of significant differences between firms as a proportion of the possible number of differences for each industry (consulting $=3$, accounting $=28$, household goods carrier $=3$ ). This figure allows for comparison across industries with different numbers of firms represented in the study.

${ }^{b}$ Entries represent the actual number of significant differences in firm means, within each industry, on each culture dimension.

dimensions except for outcome orientation. This finding suggests that future research should take industry contexts into account to fully explain the evolution and maintenance of organizational cultures.

We further examined the content and extent of cultural variation across firms and industries by considering the effects of industry membership, analyzed in terms of differences in technology and growth rates. Mixed support for Hypothesis 2 emerged: the accounting firm cultures were more innovative than the postal service culture and more team oriented than the household goods carriers and the postal service (Hypothesis 2a); the postal service was higher on stability than the other firms, and the household goods carriers were higher than the accounting firms on stability (Hypothesis $2 b$ ), lending some support to the notion that more complex technology and faster growth correspond to higher levels of innovation and team orientation and lower levels of stability - and vice versa.

But Hypotheses 2a and $2 \mathrm{~b}$ did not hold true for the consulting firms, which represented the most complex technology and highest growth. Although they ranked among the highest firms on innovation, the consulting firms were not significantly more innovative than the other industries. The relative youth of the consulting industry may partially explain this pattern. We could argue that a dominant design has not yet emerged for consulting firms, an argument that is consistent with our finding that the consulting industry had the most variation (.24) across its three firms on the seven culture dimensions. Only major product inventions, rather than incremental process improvement, may qualify as innovations (Anderson \& Tushman, 1990). The somewhat higher scores on innovation for the accounting firms and freight carriers may represent the relative ease with which process innovations are made and incorporated in those industries; this view should be tempered, however, with the relatively high variance within the accounting and carrier industries on innovation, as shown in Tables 4 and 5. A related issue, one that applies to all the dimensions, is that the meaning of being highly innovative may differ across industries, which may complicate 
TABLE 5 (continued)

\begin{tabular}{|c|c|c|c|c|c|c|c|}
\hline $\begin{array}{c}\text { Propor- } \\
\text { tion }\end{array}$ & Number & $\begin{array}{l}\text { Propor- } \\
\text { tion }\end{array}$ & Number & $\begin{array}{l}\text { Propor- } \\
\text { tion }\end{array}$ & Number & $\begin{array}{c}\text { Total } \\
\text { Number of } \\
\text { Significant } \\
\text { Differences }\end{array}$ & $\begin{array}{c}\text { Total } \\
\text { Proportion of } \\
\text { Significant } \\
\text { Differences }\end{array}$ \\
\hline .66 & 2 & 0 & 0 & 0 & 0 & 5 & .24 \\
\hline .39 & 11 & .11 & 3 & 0 & 0 & 25 & .13 \\
\hline 0 & 0 & 0 & 0 & 0 & 0 & 4 & .19 \\
\hline .38 & 13 & .09 & 3 & 0 & 0 & 34 & .14 \\
\hline
\end{tabular}

the comparison process. Although the Q-sort procedure partially addresses this issue by forcing all informants to prioritize the items, one suggestion for future research would be to collect culture information from informants who have knowledge about firm cultures in a variety of industries so that some check on the comparability of the meaning of various magnitudes of the dimensions can be assessed.

The findings for team orientation also contradicted Hypothesis 2a. The accounting firms were the most team oriented of all the industries, not the consulting firms, as predicted. Further, although the accounting firms fell between the consulting firms and the household goods carriers and postal service on detail orientation, as predicted, the highest and lowest values were the opposite of what we predicted. This pattern may be explained in part by deteriorating reputation and morale, particularly at the post office (e.g., Halliday, Goodin, \& Wernle, 1992), leading to lower commitment and less willingness among employees to do their jobs correctly and pay attention to details (e.g., Caldwell, Chatman, \& O'Reilly, 1990). Clearly, more research into the specific meaning of detail orientation is necessary to understand this finding. A broader implication of this finding is that firms whose cultures more explicitly emphasize factors related to the demands placed on them by industry technology and growth, as suggested by the second and third hypothesis sets, will be better performers in their industries. Future research could address this issue by collecting specific information about firm performance as a function of the fit between organizational culture and technology and growth rate.

We expected that intensive technology and fast growth would be associated with higher levels of team orientation, people orientation, and innovation than of detail orientation, outcome orientation, stability, and easygoingness (Hypothesis 3a); that this order would be reversed for the longlinked technology, low-growth firms (Hypothesis $3 b$ ); and that no difference among these dimensions would emerge for the mediating-technology, moderate-growth firms (Hypothesis 3c). The consulting firms' cultures were more team oriented and people oriented than easygoing, but detail and outcome orientation were the highest of the seven culture dimensions. Inter- 
estingly, outcome orientation varied substantially among the consulting firms, with the first consulting firm driving the high mean score among the firms (see Table 4). In addition, outcome orientation was the highest for all the industries (except consulting, in which it was second highest), suggesting that it may be generally emphasized among firms in the service sector.

The postal service culture's pattern closely resembled our prediction, except it was less easygoing than expected. But the household goods carriers, which we also classified as having a long-linked technology and low growth, more closely resembled our prediction for the mediatingtechnology, moderate-growth firms since the dimensions varied only slightly among the three firms, and least of the other two industries with multiple firms (.13, see Table 5). In contrast, the mediating-technology firms in the moderate-growth industry showed significant variance across the dimensions. Interestingly, the two highest and lowest are dimensions we associated with long-linked technology and low growth, and the three middle dimensions are those we associated with intensive technology and high growth. This pattern may suggest, albeit indirectly, that the accounting firms' cultures represent some melding of the patterns we predicted for the more extreme ends of the technology and growth continuum.

These results are more complex than what we predicted. Our results clearly support the notion that industry membership accounts for variance in culture patterns (Hypothesis 1), but it is less clear that technology and growth are the sole influences on the culture patterns that emerged (hypothesis sets 2 and 3). One explanation for our mixed results is that Thompson's (1967) typology may not be a simple continuum, as we assumed. Firms that relied on mediating technologies and experienced moderate growth (the accounting firms) were more team oriented and less people oriented than either of the other two types. This finding suggests that the sorting or categorizing focus of mediating technologies lends itself to team orientation. The results for the accounting firms (i.e., highest on team orientation and outcome and lowest on stability and people orientation) are consistent with previous research (e.g., Hitt, 1976; Rousseau, 1978) showing that Thompson's classification is not ordinal and that mediating technologies usually fall on the extremes rather than in between long-linked and intensive technologies. Future research may benefit by treating Thompson's typology categorically rather than ordinally.

Alternatively, we may have incorrectly classified the industries represented in our study. Specifically, the postal service and freight carrier firms were classified as using long-linked technologies, when their technologies are actually mediating. Further, technology and growth may not always match. This concern raises an issue about our group of firms: although it is more complete than most in that it includes multiple firms from multiple industries, it does not include the entire range of possible firms and industries. Multiple firms representing each of the technology and growth types could be useful to determine the range in the levels of the culture dimen- 
sions. Our focus on service sector firms exacerbates the restricted range problem. In all industries within the service sector, some linking function between clients and an organization is performed, by the very definition of service; all service sector industries may therefore use mediating technology to some extent. Perhaps including manufacturing firms with clear assembly line tasks would yield results that more clearly fit the second and third hypothesis sets. Control over sector was required in this initial research on industry and culture, but subsequent research should include enough firms and industries to compare across sectors statistically, a nontrivial data collection challenge.

This study was a first step toward generating more systematic assessments of industry effects on organizational culture. Judging from the results of this study, however, it is clear that future research should identify other important characteristics of industrial and organizational task environments and relate these to organizational cultures. For example, regulation may be an important component driving cultural homogeneity among firms in an industry, a notion supported by the relatively smaller internal differences among the accounting firms and the larger variation among the less regulated consulting firms. Product life cycles may also influence organizational culture. For example, consulting firms may be more concerned with differentiating their still rather heterogeneous offerings (e.g., Kelley, 1986) than accounting firms, whose primary products (audits and tax work) are further along in their life cycles. In addition, industry event history analyses may be helpful for explaining the dynamic nature of organizational culture. For example, the postal service culture may be immersed in a major cultural change because of the negative publicity generated by several on-site homicides (e.g., Halliday et al., 1992). Finally, researchers could realize a fuller understanding by simultaneously focusing on internal influences on organizational culture, such as executive succession and layoffs, and industry influences on organizational culture.

Other characteristics specific to the service sector may relate to an organization's culture, including how customized a service is, the nature of service delivery, the duration of the relationship to the customer, and demand and supply fluctuations (Normann, 1984). For example, employees tend to be very mobile within the service sector (Lovelock, 1983). Future research could examine constraints generated by cultural dissimilarity on employee mobility. Conversely, product innovation has been attributed to employee mobility within an industry, and therefore, organizational cultures may become more similar as employees move across firms in the same industries (Freeman, 1982; Schneider, 1987).

Although this study suggests a link between industry characteristics and organizational culture, it does not answer the developmental question of how similarities in same-industry cultures form. Research that can address the causal chain from industry characteristics to organizational values and norms is essential. Further, the specific mechanisms of technology that affect organizational culture deserve further investigation. Is it the interaction 
aspect of technology (how much people need to work together) or the degree of standardization dictated by technology or growth that affects a culture? Research has already shown that technology can influence communication (Van De Ven, Delbecq. \& Koenig, 1976). Such communication may in turn act as the mechanism that promotes cultural values, such as being people oriented or easygoing (Jablin, 1987).

Also, although our study examined the association between growth and innovation, their causal relationship is still open to question. Previous research has suggested that growth causes innovation. For example, Thompson (1967) claimed that firms in high-growth industries are more capable of developing and improving products. Gordon (1991) also argued that growth influences risk taking, flexibility, and adaptability. The constantly increasing revenues and opportunities that characterize fast growth result in slack resources. These can be used for innovative developments and enable organizations to be more adaptable. But a compelling argument for innovation leading to growth can also be made. Creativity and flexibility can cause high growth rates among same-industry firms if the innovations are successfully implemented or if flexibility leads to successful adaptation. The design of the present study did not permit a test of the direction of causality, but future research should address this issue.

Strategic analysts are concerned with identifying their competitors' motives to develop an effective strategy for competing in an industry (e.g., Kotter \& Heskett, 1992; Porter, 1980). But such analyses should be tempered by the findings from this study - firms in similar industries may face constraints on how distinct their cultures can actually be and thus the extent to which culture can be used as a source of competitive advantage. In contrast, one might argue that rather than attempting to establish unique cultures, firms should consider the benefits of imitating the cultures of successful players in their industries. This idea is consistent with an institutional perspective: firms that are able to identify the cultural characteristics of the largest players in their industries may be better able to adopt those characteristics (e.g., Zucker, 1977). Such adoption may actually assist new or small firms in establishing and promoting legitimacy and performing effectively. But future research is necessary to determine the conditions under which imitation, as suggested above, would be appropriate. For example, cultural imitation may be most advantageous in industries with stable environments, where the dominant firms have established a strategic, operational, and cultural formula that works and will continue to work because of environmental stability. In contrast, mimicking successful organizations in industries undergoing environmental turbulence may be a recipe for failure, as might have been the case for personal computer manufacturers who mimicked the International Business Machines Corporation (IBM). Regardless of the specific prescriptive formulas generated, this study provides evidence for a conceptual and empirical link between industry characteristics and organizational culture that warrants further investigation. 


\section{REFERENCES}

Aldrich, H. 1972. Technology and organizational structure: A reexamination of the findings of the Aston group. Administrative Science Quarterly, 17: 26-43.

$\rightarrow$ Anderson, P., \& Tushman, M. L. 1990. Technological discontinuities and dominant designs: A cyclical model of technological change. Administrative Science Quarterly, 35: 604-633.

Association of Management Consultant Firms. 1987. ACME 1987 survey of key management information. New York: Association of Management Consultant Firms.

$\rightarrow$ Barney, J. B. 1986. Organizational culture: Can it be a source of sustained competitive advantage? Academy of Management Review, 11: 656-665.

Bem, D. J., \& Funder, D. C. 1978. Predicting more of the people more of the time: Assessing the personality of situations. Psychological Review, 85: 485-501.

Block, J. 1978. The Q-sort method in personality assessment and psychiatric research. Palo Alto, CA: Consulting Psychologists Press.

$\rightarrow$ Boeker, W. 1989. Strategic change: The effects of founding and history. Academy of Management Journal, 32: 489-515.

Bravermann, H. 1974. Labor and monopoly capital: The degradation of work in the twentieth century. New York: Monthly Review.

Caldwell, D. F., Chatman, J. A., \& O'Reilly, C. A. 1990. Building organizational commitment: A multifirm study. Journal of Occupational Psychology, 63: 245-261.

Candilis, W. 1988. United States service industries handbook. New York: Praeger.

$\rightarrow$ Chatman, J. 1989. Improving interactional organizational research. A model of person-organization fit. Academy of Management Review, 14: 333-349.

$\rightarrow$ Chatman, J. 1991. Matching people and organizations: Selection and socialization in public accounting firms. Administrative Science Quarterly, 36: 459-484.

Cliff, N. 1987. Analyzing multivariate data. New York: Harcourt Brace Jovanovich.

Cyert, R., \& March, J. 1963. A behavioral theory of the firm. Englewood Cliffs, NJ: PrenticeHall.

Dansereau, F., \& Alluto, J. 1990. Level-of-analysis issues in climate and culture research. In B. Schneider (Ed.), Organizational climate and culture: 193-236. San Francisco: JosseyBass Publishers.

Darnay, A. J. 1992. Service industries USA. Detroit: Gale Research.

Darnay, A. J., \& Reddy, M. A. 1992. Market share reporter: An annual compilation of reported market share data on companies, products, and services. Detroit: Gale Research.

Deal, T., \& Kennedy, A. 1982. Corporate cultures. Reading, MA: Addison-Wesley.

Denison, D. R. 1990. Corporate culture and effectiveness. New York: Wiley.

$\rightarrow$ Dess, G., \& Beard, D. 1984. Dimensions of organizational task environments. Administrative Science Quarterly, 29: 52-73.

Dess, G., Ireland, R., \& Hitt, M. 1990. Industry effects and strategic management research. Journal of Management, 16: 7-27.

$\rightarrow$ Dewar, R., \& Hage, J. 1978. Size, technology, complexity, and structural differentiation: Toward a theoretical synthesis. Administrative Science Quarterly, 23: 111-136.

$\rightarrow$ Enz, C. 1988. The role of value congruity in intraorganizational power. Administrative Science Quarterly, 33: 284-304.

Freeman, J. 1982. Organizational life cycles and natural selection processes. In B. M. Staw \& L. L. Cummings (Eds.), Research in organizational behavior, vol. 4: 1-32. Greenwich, CT: JAI Press. 
George, W., \& Marshall, C. 1984. Developing new services. Chicago: American Marketing Association.

Gordon, G. 1985. The relationship of corporate culture to industry sector and corporate performance. In R. H. Kilmann, M. J. Saxton, \& R. Serpa (Eds.), Gaining control of the corporate culture: 103-125. San Francisco: Jossey-Bass.

$\rightarrow$ Gordon, G. 1991. Industry determinants of organizational culture. Academy of Management Review, 16: 396-415.

Gort, M. 1962. Diversification and integration in American industry. Princeton, NJ: Princeton University Press.

Gramlach, E. 1985. Government services. In R. Inman (Ed.), Managing the service economy: 273-294. New York: Cambridge University Press.

Green, P. 1978. Mathematical tools for applied multivariate analysis. New York: Academic Press.

Grinyer, P. H., \& Spender, J. C. 1979. Turnaround: Managerial recipes for strategic success. London: Associated Business Press.

Halliday, J., Goodin, M., \& Wernle, B. 1992. Crisis in Royal Oak. Crain's Detroit Business, February 24: 6 .

$\rightarrow$ Harrison, J. R., \& Carroll, G. R. 1991. Keeping the faith: A model of cultural transmission in formal organizations. Administrative Science Quarterly, 36: 552-582.

Hitt, M. A. 1976. Technology, organizational climate and effectiveness. Journal of Business Research, 4: 383-399.

Hitt, M. A., \& Middlemist, D. 1978. The measurement of technology within organizations. Journal of Management, 4: 47-67.

$\rightarrow$ Hofstede, G., Neuijen, B., Ohayv, D., \& Sanders, G. 1990. Measuring organizational cultures: A qualitative and quantitative study across twenty cases. Administrative Science Quarterly, 35: $286-316$.

Household Goods Carriers Bureau. 1992. Moving industry statistics. Alexandria, VA: Household Goods Carriers Publications.

Jablin, F. 1987. Organizational entry, assimilation, and exit. In F. Jablin, L. Putnam, K. Roberts, \& L. Porter (Eds.), Handbook of organizational communication: 679-740. Newbury Park, CA: Sage.

$\rightarrow$ Jelinek, M. 1977. Technology, organizations, and contingency. Academy of Management Review, 2: $17-26$.

Jerimer, J. M., Slocum, J. W., Fry, L. W., \& Gaines, J. 1991. Organizational subcultures in a soft bureaucracy: Resistance behind the myth and facade of an official culture. Organization Science, 2(3): 170-194.

$\rightarrow$ Jones, A. P., \& James, L. R. 1979. Psychological climate: Dimensions and relationships of individual and aggregated work environment perceptions. Organizational Behavior and $\mathbf{H u}$ man Performance, 23: 201-250.

$\rightarrow$ Jones, A. P., Johnson, L. A., Butler, M. C., \& Main, D. S. 1983. Apples and oranges: An empirical comparison of commonly used indices of interrater agreement. Academy of Management Journal, 26: 507-519.

$\rightarrow$ Joyce, W. F., \& Slocum, J. W., Jr. 1984. Collective climate: Agreement as a basis for defining aggregate climates in organizations. Academy of Management Journal, 27: 721-742.

Kanter, R. 1988. When a thousand flowers bloom: Structural, collective, and social conditions for innovation in an organization. In B. M. Staw \& L. L. Cummings (Eds.), Research in organizational behavior, vol. 10: 169-211. Greenwich, CT: JAI Press. 
Katz, D., \& Kahn, R. L. 1966. The social psychology of organizations. New York: Wiley.

Kelley, R. 1986. Consulting. New York: Scribner's Sons.

Kotter, J. P., \& Heskett, J. L. 1992. Corporate culture and performance. New York: Free Press.

Kubr, M. 1976. Management consulting: A guide to the profession. Geneva: International Labour Organization.

Lewis, W., Siemen, A., Ballay, M., \& Sakate, K. 1992. Service sector productivity and international competitiveness. McKinsey Quarterly, 4(4): 69-91.

Lovelock, C. H. 1983. Classifying services to gain strategic marketing insights. Journal of Marketing, 47(3): 9-20.

Magnet, M. 1993. Good news for the service economy. Fortune, 127(9): 46-52.

$\rightarrow$ Martin, J., Feldman, M., Hatch, M., \& Sitkin, S. 1983. The uniqueness paradox in organizational stories. Administrative Science Quarterly, 28: 438-453.

Morrison, E. W. 1993. Longitudinal study of the effects of information seeking on newcomer socialization. Journal of Applied Psychology, 78: 173-183.

Normann, R. 1984. Service management: Strategy and leadership in service businesses. New York: Wiley.

Nunnally, J. 1967. Psychometric theory. New York: McGraw-Hill.

O'Reilly, C. 1989. Corporations, culture, and commitment: Motivation and social control in organizations. California Management Review, 31: 9-25.

$\rightarrow$ O'Reilly, C., Chatman, J., \& Caldwell, D. 1991. People and organizational culture: A Q-sort approach to assessing person-organization fit. Academy of Management Journal, 34: 487 516.

$\rightarrow$ Ouchi, W., \& Johnson, J. 1978. Types of organizational control and their relationship to emotional well-being. Administrative Science Quarterly, 23: 293-318.

Pennings, J., \& Gresov, C. 1986. Technoeconomic and structural correlates of organizational culture. Organization Studies, 7: 317-334.

Pennings, J., \& Harianto, F. 1992. Technological networking and innovation implementation. Organization Science, 3: 356-382.

$\rightarrow$ Perrow, C. 1967. A framework for the comparative analysis of organizations. American Sociological Review, 32: 194-208.

Pfeffer, J. 1982. Organizations and organization theory. New York: Harper \& Row.

Pfeffer, J., \& Salancik, G. 1978. The external control of organizations. New York: Harper \& Row.

Phillips, M. 1991. The cultural context of industry: Distinct sets of assumptions in fine arts museums and wineries. Paper presented at the annual meeting of the Academy of Management, Miami Beach.

Porter, M. 1980. Competitive strategy. New York: Free Press.

Quinn, R. E., \& Rohrbauch, J. 1983. A spatial model of effectiveness criteria: Towards a competing values approach to organizational analysis. Management Science, 29: 363-377.

Rosner, M. M. 1968. Economic determinants of organizational innovation. Administrative Science Quarterly, 12: 614-625.

Rousseau, D. 1977. Technological differences in job characteristics, employee satisfaction, and motivation: A synthesis of job design research and sociotechnical systems theory. Organizational Behavior and Human Performance, 19: 18-42.

Rousseau, D. M. 1978. Characteristics of departments, positions, and individuals: Contests for attitudes and behavior. Administrative Science Quarterly, 23: 521-540. 
Rousseau, D. 1990. Quantitative assessment of organizational culture: The case for multiple measures. In B. Schneider (Ed.), Frontiers in industrial and organizational psychology, vol. 3: 153-192. San Francisco: Jossey Bass.

$\rightarrow$ Sackmann, S. 1992. Culture and subcultures: An analysis of organizational knowledge. Administrative Science Quarterly, 37: 140-161.

$\rightarrow$ Saffold, G. 1988. Culture traits, strength, and organizational performance: Moving beyond "strong" culture. Academy of Management Review, 13: 546-558.

Sampson, R., Farris, M., \& Shrock, D. 1985. Domestic transportation: Practice, theory, and policy. Dallas: Houghton-Mifflin.

Saxenian, A. 1990. Regional networks and the resurgence of Silicon Valley. California Management Review, 32: 89-112.

Schein, E. 1985. Organizational culture and leadership. San Francisco: Jossey-Bass.

Schneider, B. 1987. The people make the place. Personnel Psychology, 14: 437-453.

Selznick, P. 1957. Leadership in administration. New York: Harper \& Row.

$\rightarrow$ Sheridan, J. E. 1992. Organizational culture and employee retention. Academy of Management Journal, 35: 1036-1056.

Stevens, M. 1981. The big eight. New York: McGraw-Hill.

Thompson, J. 1967. Organizations in action. New York: McGraw-Hill.

United States Department of Commerce. 1985. U.S. industrial outlook '85. Washington, DC: International Trade Administration.

United States Department of Commerce. 1989. U.S. industrial outlook '89. Washington, DC: International Trade Administration.

United States Department of Commerce. 1992. U.S. industrial outlook '92. Washington, DC: International Trade Administration.

United States Postal Service. 1986. Annual report of the postmaster general: Fiscal 1985. Washington, DC: United States Postal Service.

United States Postal Service. 1988. Annual report of the postmaster general: Fiscal 1987. Washington, DC: United States Postal Service.

United States Postal Service. 1992a. Annual report of the postmaster general: Fiscal 1991. Washington, DC: United States Postal Service.

United States Postal Service. 1992b. Human resources information system education level counts. Washington, DC: United States Postal Service.

$\rightarrow$ Van De Ven, A., \& Delbecq, A. 1974. A task contingent model of work unit structure. Administrative Science Quarterly, 19: 183-197.

$\rightarrow$ Van De Ven, A., Delbecq, A., \& Koenig, R. 1976. Determinants of coordination modes within organizations. American Sociological Review, 41: 322-338.

Van Maanen, J., \& Barley, S. 1984. Toward a theory of organizational socialization. In B. M. Staw \& L. L. Cummings (Eds.), Research in organizational behavior, vol. 6: 287-366. Greenwich, CT: JAI Press.

Weiner, Y. 1988. Forms of value system: A focus on organizational effectiveness and cultural change and maintenance. Academy of Management Review, 13: 534-545.

$\rightarrow$ Wilensky, H. 1964. The professionalization of everyone? American Journal of Sociology, 70: $137-158$.

$\rightarrow$ Wilkins, A., \& Ouchi, W. 1983. Efficient cultures: Exploring the relationship between culture and organizational performance. Administrative Science Quarterly, 28: 468-481. 
$\rightarrow$ Zammuto, R., \& O'Connor, E. 1992. Gaining advanced manufacturing technologies' benefits: The roles of organization design and culture. Academy of Management Review, 17: 701728.

Zammuto, R., \& Krakower, J. 1991. Quantitative and qualitative studies of organizational culture. In R. W. Woodman \& W. A. Pasmore (Eds.), Research in organizational change and development, vol. 5: 83-114. Greenwich, CT: JAI Press.

$\rightarrow$ Zucker, L. 1977. The role of institutionalization in cultural persistence. American Sociological Review, 42: 726-743.

Jennifer A. Chatman is an assistant professor of organizational behavior at the Haas School of Business, University of California, Berkeley, where she received her Ph.D. degree. Her current research interests include studies of person-culture fit and the interactive effects of person and situation characteristics on individual behavior.

Karen A. Jehn is an assistant professor of management at the Wharton School of the University of Pennsylvania. She received her Ph.D. degree in organization behavior from the Kellogg Graduate School of Management, Northwestern University. Her current research is in the areas of intragroup and intergroup conflict, strategic decision making, deception in organizations, and cross-industry and cross-national comparisons of values, beliefs, goals, and conflict styles. 